\title{
Bwindi Impenetrable National Park, Uganda: gorilla census 1997
}

\author{
Alastair McNeilage, Andrew J. Plumptre, Andrew Brock-Doyle and Amy Vedder
}

\begin{abstract}
Bwindi Impenetrable National Park in south-west Uganda supports a population of gorillas that has become the primary gorilla population for tourism following the genocide in Rwanda. Previous estimates made in the early 1990s indicated that the population numbered around 300 individuals. The census reported here was the first in Bwindi to use the method successfully developed in the Virungas, which utilizes a complete sweep across the park within a short period of time by a large number of teams working simultaneously. We estimated the population to be 292 individuals; to the best of our understanding - based on previous estimates - the population, therefore, appears to be stable. Most gorillas were found within the centre of the southern section of the park. It appears that there
\end{abstract}

are some areas of unused habitat and, therefore, room for the population to grow. We found no clear relationship between gorilla distribution and human presence, but some forms of disturbance were more frequent and close to the edge of the park and may contribute to the gorillas' avoidance of these areas. The effects of human disturbance, including tourism, on the gorillas and other wildlife should be investigated in more detail and monitored over time. This is particularly important in multiple-use zones which have been established around the edges of the park for bee-keeping, collection of nontimber forest products, and tourism.

Keywords Bwindi, gorillas, human impact, population size, Uganda.

\section{Introduction}

The Bwindi Impenetrable National Park in south-west Uganda is best known for its gorilla population. The gorillas attract tourists to the forest and generated up to 50 per cent of the income of Uganda's national park system before an incident in March 1999 when eight tourists and one park warden were murdered by Rwandan rebels coming from the Democratic Republic of Congo (DRC). After the genocide in Rwanda in 1994 and the following insecurity in that country, Bwindi has become the main destination for gorilla tourism. Since the early 1980s, the Bwindi gorillas were considered to be the same subspecies (Gorilla gorilla beringei) as those found in the Virungas (Plate 1), a string of volcanoes on the border of Rwanda, Uganda and the DRC (25 km from Bwindi). This has been disputed by Sarmiento et al. (1996), using skeletal measurements and phenotypic differences, and suggested differences in ecology and behaviour. However, their contention that Bwindi gorillas should be given a different subspecies is not supported by genetic studies, which show very little variation

Andrew J. Plumptre (corresponding author) Plot 32 Lutowa Estate, PO Box 7487, Kampala, Uganda. E-mail: aplumptre@wcs.org

Alastair McNeilage and Amy Vedder Wildlife Conservation Society, 185th Street and Southern Boulevard, Bronx, NY 10460, USA

Andrew Brock-Doyle International Gorilla Conservation Programme, PO Box 10950, Kampala, Uganda

Revised manuscript accepted for publication 2 August 2000 between the two populations (O. Ryder \& M. Seaman, pers. comm.). Many of the skeletal measurements were based on a very small sample size $(n=3-5)$. In addition, the information on gorilla ecology in the Virungas on which their comparisons are based comes from some of the highest altitudes occupied by gorillas. Gorillas also occupy lower altitudes within the Virungas, at a comparable altitude to much of Bwindi, where their habitat and ecology is likely to be more similar. Very little data have been published on the ecology and behaviour of gorillas at low altitudes in the Virungas or in Bwindi. Thus, comparisons of the two are not possible at present. The taxonomic status of the population therefore is as yet unclear. For the remainder of this report we will continue to refer to these two populations as Bwindi and Virunga gorilla populations, respectively.

The Virunga gorilla population has been the subject of much research and several censuses over the last 30 years (Harcourt et al., 1983; Weber \& Vedder, 1983; Vedder, 1986; Sholley, 1991). Before the outbreak of civil war in the area in 1990, the population was estimated to be 310 individuals (Sholley, 1991). It is not known how the war has affected the population, although several incidents have been reported in which gorillas have been killed (as many as 15 may have been killed in DRC alone; Sikubwabo \& Mushenzi, 1997; Stewart, 1998; V. Katembo, pers. comm.), and the future protection of the area is far from being assured. Much of the area on the Congolese side is still inaccessible to park personnel, although since early 1999 guards and trackers have been able to patrol and contact certain gorilla groups when 


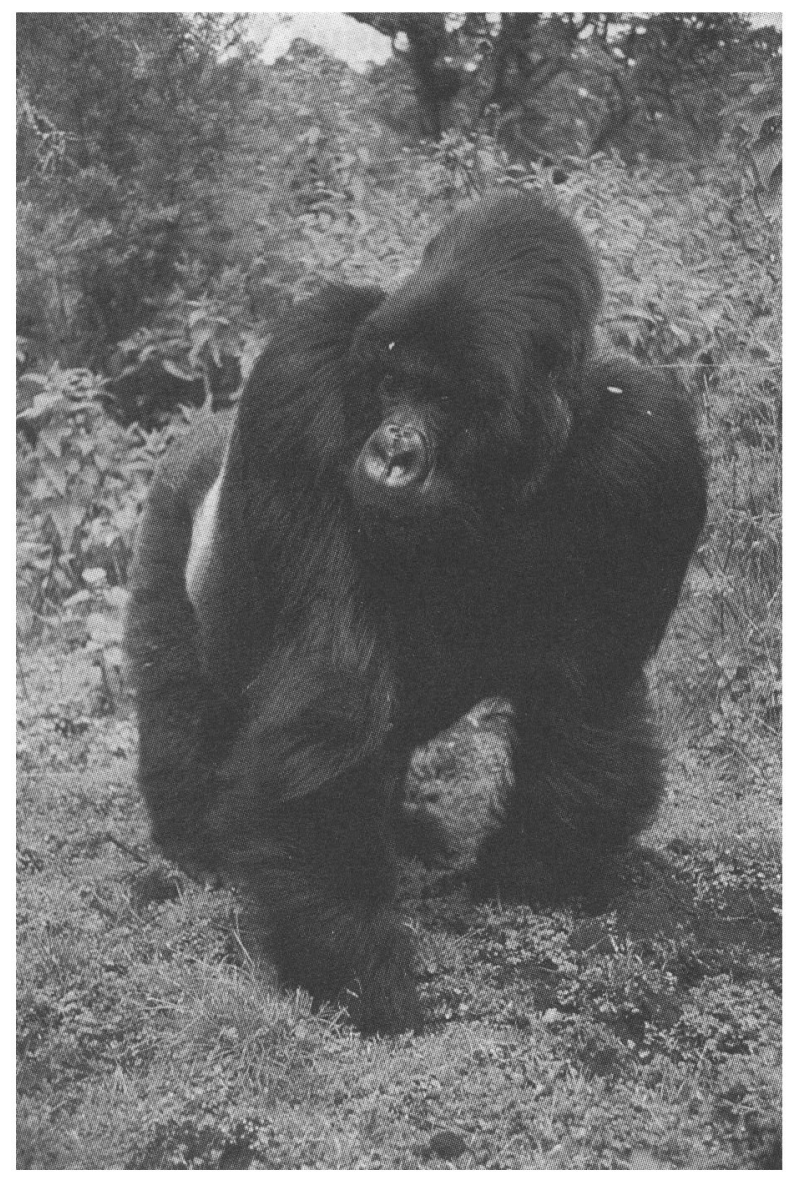

Plate 1 Gorillas in Bwindi differ in some respects from those in the Virunga volcanoes. Whether these differences are enough to make them a separate subspecies is currently the topic of a hot debate (Andrew Plumptre)

accompanied by military patrols. The numbers of gorillas in habituated groups appear to have remained fairly stable or have even increased. Thus, it would appear that the population has not declined as a result of the war. In 1999, tourism was reopened in Rwanda and the number of visitors have been increasing steadily.

The Bwindi population is less well known, although given the situation in the Virungas and the gorilla's possible revised taxonomic status, its conservation is all the more critical. Schaller (1963), in a short survey of 20 days, estimated that there were between 120 and 180 individuals in 1959. Later estimates of the population, based on similarly limited surveys, were 116 (Harcourt, 1981) and 146 (Butynski, 1985). Later, T.M. Butynski (pers. comm.) repeatedly censused all groups over a 7-year period up to mid-1993, during which time the population remained stable at around 300 individuals (Butynski \& Kalina, 1993). Why the estimates increased so much is not certain but if the short surveys tended to focus more effort near the periphery of the forest then it is possible that they did not visit the areas where the gorillas tend to be found (Harcourt, 1981; Butynski, 1985; this study). In order to census gorilla populations accurately, a number of teams must cover the area concerned simultaneously in a continuous sweep from one side to the other so that as short a time as possible is taken to census the population. This method has been successfully used several times for the Virunga gorilla population (Vedder, 1986; Sholley, 1991) and the approach was used here.

This report describes a census carried out jointly by the Uganda Wildlife Authority (UWA), the Wildlife Conservation Society (WCS), the International Gorilla Conservation Programme (IGCP) and the Institute of Tropical Forest Conservation (ITFC) between 4 October and 18 November 1997. Two previous surveys in Bwindi indicated that human disturbance, in the form of agricultural encroachment, pitsawing, hunting and gold mining, had an impact on gorilla distribution and use of particular areas (Harcourt, 1981; Butynski, 1985). Both found that gorillas tend to use the more inaccessible interior parts of the forest, whereas human activity tends to be more concentrated in the periphery. In 1991, Bwindi was gazetted as a national park; prior to this it had been a Forest Reserve and Game Reserve. Since the mid-1980s, game and then park rangers have succeeded in greatly reducing the prevalence of the main forms of human disturbance (Butynski \& Kalina, 1993) as a result of increased financial support to the forest and a reduction in civil war and insecurity in Uganda. However, no data are available on the intensity and distribution of disturbance since gazetting. Signs of gorilla use and signs of illegal human disturbance are negatively correlated in the Virungas (McNeilage, 1995) suggesting that disturbance still has an impact on gorillas there, despite national park status and considerable antipoaching efforts. In addition to producing an accurate count of the gorilla population size and composition, the Bwindi census aimed to investigate the intensity and distribution of illegal human disturbance and to examine its possible impact on the gorillas.

\section{The Bwindi Impenetrable National Park}

The Bwindi Impenetrable National Park is a montane forest ranging between 1160 and $2607 \mathrm{~m}$ altitude in south-western Uganda $\left(0^{\circ} 53^{\prime}-1^{\circ} 08^{\prime} \mathrm{N}\right.$; $\left.2^{\circ} 35^{\prime}-29^{\circ} 50^{\prime} \mathrm{E}\right)$. The forest was initially gazetted as a forest reserve in 1932 (Howard, 1991) and became a national park in 1991 (Butynski \& Kalina, 1993) to protect its population of gorillas and its rich plant and bird diversity (Hamilton, 1976; Keith, 1980; Butynski, 1984; Davenport et al., 1996). The park is approximately $331 \mathrm{sq} \mathrm{km}$ of extremely 


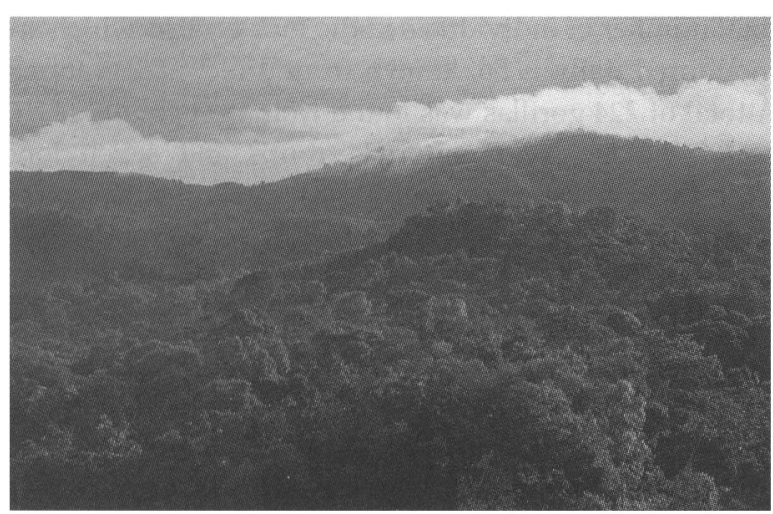

Plate 2 Bwindi Impenetrable National Park is made up of many peaks, steep slopes and valleys, all of which are forested (Andrew Plumptre).

rugged country characterized by numerous steep-sided hills and narrow valleys (Plate 2). A narrow neck of forest of about $1 \mathrm{~km}$, traversed by a road, divides the park into northern and southern parts (Fig. 1).

The park is surrounded by a high human population, which in 1991 averaged 220 people per sq $\mathrm{km}$, growing at a rate of about 2.7 per cent per year (Gubelman et al., 1995). Human use of this forest was extensive in the past, with pitsawing for timber and agricultural encroachment causing the greatest damage. When Bwindi became a national park, all pitsawing was banned. However, multiple-use zones have been established for the harvesting of medicinal plants and bee-keeping, and a zone has been established for tourism in the form of gorilla visits and forest walks (Gubelman et al., 1995).

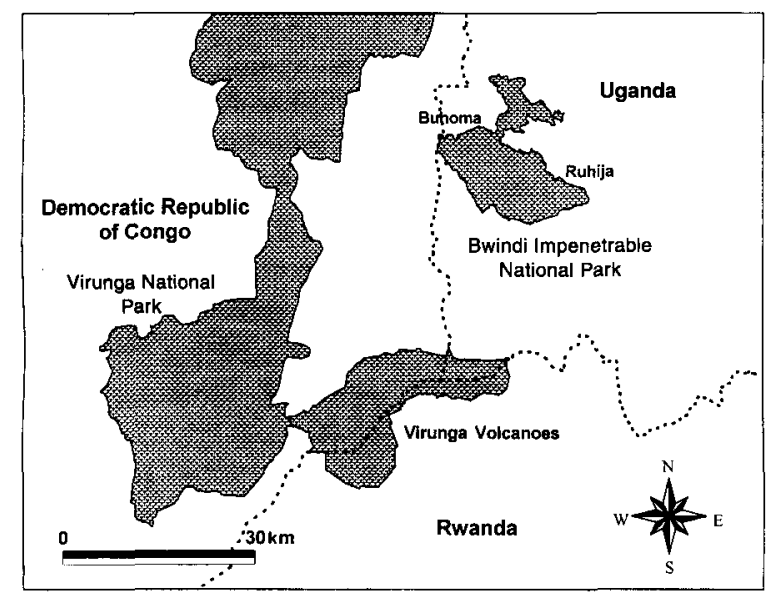

Fig. 1 Map of south-west Uganda including the border regions of Rwanda and DRC showing the location of protected areas (stippled). The Virunga volcanoes encompass three parks: the Parc National des Volcans (Rwanda), the Mgahinga National Park (Uganda) and the Parc National des Virungas (DRC). Buhoma is the site of the gorilla tourism and Ruhija is the site of the ITFC, the research station in Bwindi.
Both tourism and the multiple-use zones can have an impact on the forest (Butynski \& Kalina, 1998).

\section{Methods}

\section{Gorilla census methods}

Six teams, each consisting of at least two experienced trackers and one or two team leaders, traversed the park systematically from south-east to north-west between 4 October and 18 November 1997. The park was divided into 39 small sectors (between 5 and $10 \mathrm{sq} \mathrm{km}$ ), centred around campsites and access points (see Fig. 3). One team was assigned to conduct a census in each sector, proceeding so that no more than 3 days were left between the completion of work in one sector and the beginning of work in the next, contiguous sector. Two teams generally worked in neighbouring sectors from one campsite, to allow better co-ordination of movements and comparisons of findings each day.

Within each sector, census teams walked an irregular network of survey routes, using existing trails and animal paths, and cutting trails as necessary. When recent gorilla trail was found (less than approximately 5 days old), it was followed until at least three night nest sites were located. The actual pattern of trails walked before finding gorilla trail was largely determined by the terrain, and was sufficiently dense so that all areas within which a gorilla group could spend more than 5 days were entered. To achieve this, the distance between adjacent survey routes was never greater than 500$700 \mathrm{~m}$. Using topographic maps, along with GPS and altimeter readings, all routes walked and gorilla trails followed were mapped. By covering the area in this way, mapping and dating all gorilla trails and nest sites, and by marking nest sites encountered with cut stakes, the risk of missing groups and of double counting groups was minimized. It was also possible to distinguish similar sized but distinct gorilla groups found close to each other, provided that group composition differed.

At each nest site, nests were counted and dung size measurements were used to establish the age-sex composition of the group. Measurements were taken across the broadest part of dung which was not crushed or disintegrated. As no data were available on dung size classes for Bwindi gorillas, the dung size classes established by Schaller (1963) were used. In the course of the census, these were checked using dung sizes from nests for which the age-sex class could be determined by other clues, such as the presence of many long silver hairs for adult males, or infant dung for adult females. By using the presence of hairs or infant dung, and a lower limit of $5.5 \mathrm{~cm}$ for adult female dung (which turned out to be the same as Schaller's figure for the 
Virungas), we could reliably determine the age-sex class for each nest. Young individuals constructing their own nest were always considered here as the combined category juveniles/subadults, and not infants. In the absence of infant dung, adult female nests could not be distinguished from those of a comparable sized subadult (blackback) male. At least three nest sites were counted for each group to ensure that an accurate, consistent group size and composition was established. Where this could not be established after three nest sites, additional sites were located.

Dung of young infants (less than approximately one year old) was rarely found in nests, and so the number of infants in the population will have been underestimated by these methods. However, the compositions of four groups which have been habituated for research or tourism are known from direct observations. The composition of these groups was also established from nest sites using the same techniques as for the rest of the population, so that an estimate of the proportion of infants missed by nest counts could be calculated.

\section{Surveys of human disturbance and gorilla signs}

While walking survey routes, all signs of illegal human disturbance were recorded, with the location and estimated age of each. These included snares, pitfall traps, human tracks, poachers' camps/fireplaces, pitsawing sites, wood and bamboo cutting, honey collection, poachers and beehives (although many of these were legally placed within multiple-use zones). All gorilla nest sites were noted, whether or not they were associated with fresh trail, which was then followed. Routes travelled each day were plotted on topographic maps using GPS positions, contours and other features. The distance travelled along survey routes was measured from these maps using an electronic map measurer and checked against a sample of routes measured on the ground with a hipchain. There was a good correlation between the two measurements $(r=0.975, n=64$, $P<0.001$ ). Distance measured on the maps underestimated actual distance walked. A correction factor of 12.4 per cent was calculated from the mean error and used to correct map distances. A total of $548.4 \mathrm{~km}$ of survey routes was walked during the census, with a mean of $14.1 \mathrm{~km}$ (range $3.6-26.7 \mathrm{~km}$ ) per sector. Signs were analysed as encounter rates per $\mathrm{km}$ walked in each sector.

\section{Results}

\section{The gorilla population}

Twenty-eight gorilla groups and seven lone males were found during the course of the census (Table 1). The total number of individuals in the four groups which are monitored daily is 56, known from direct observations. A total of 224 gorillas was found from nest counts of the remaining 24 non-monitored groups and seven lone males. Comparable nest counts were obtained for three of the four monitored groups. These three groups were known to include 13 infants (i.e. those sharing nests with their mothers) of which five (38 per cent) were not detected in the nest counts. Assuming that the same proportion of infants was missed in the nest counts of the non-monitored groups, where 32 infants were counted, we can estimate that an additional 12 infants were missed. This gives a total population estimate of 292 individuals. The count should be considered a minimum because some small groups or lone silverbacks from neighbouring groups of similar size could either have been missed or confused with similar sized neighbouring groups (if group composition was identical). If any doubt existed as to whether a nest count belonged to a new or a counted group, it was assumed to be a double count of a counted group. However, in considering how intensively the area was covered, we feel that it is unlikely that more than two or three small groups could have been missed in this way. The fact that all of the regularly monitored groups, as well as neighbouring groups known to trackers and guides, were found during the census, without prior knowledge of their locations, indicates that the census methods worked acceptably well. We therefore argue that an estimate of 300 individuals should be used for the Bwindi gorilla population. This is the same as Butynski's estimate made in the early 1990s (Butynski \& Kalina, 1993; Sarmiento et al., 1996). Within the limits of the methods used, the population appears to be stable.

Groups ranged in size between 2 and 23 individuals, with a mean of 9.8 (SD 6.2) or 10.2 after allowing for undetected infants. This may be higher than the figure of 7.2 obtained in 1984 (Butynski, 1985), but the latter is based on a limited proportion of the population (nine groups) and no error estimates were made so that the two estimates cannot be tested to determine whether the difference is significant. Harcourt (1981) estimated a median group size of 9.0 , which is similar. Average group size in Bwindi is comparable with that in the Virungas (9.15, Sholley, 1991). Of the 28 groups, 15 contained one silverback, whereas eight had two silverbacks and five had three silverbacks, so that 46 per cent of groups were multi-male. This is considerably higher than the figure of 29 per cent in the most recent Virunga census (Sholley, 1991), but comparable with earlier figures for the Virungas (M. Robbins, pers. comm.).

The proportion of immature gorillas (i.e. infants plus juvenile and subadults) in the population within groups was 37 per cent, which is comparable with that found 
Table 1 The composition of all gorilla groups found during the 1997 Bwindi gorilla census. For monitored groups, the known composition is given, rather than that determined from nest counts during the census. Habituation teams had recently started to follow one other group (U1-AP, also known as the Nkuringo group), but it was not well known to allow group composition to be determined independently of nest counts, and was not therefore included here as a monitored group. The category of 'Other adult' was assigned to nests with dung where it couldn't be determined if it was a blackback male or a female with no infant as both of these will produce dung of a similar size (see Fig. 2 for location of gorilla groups).

\begin{tabular}{|c|c|c|c|c|c|c|c|}
\hline Group ID & Sector & Silverback & Female & Other adults & $\begin{array}{l}\text { Juvenile/ } \\
\text { subadults }\end{array}$ & Infants & Total \\
\hline \multicolumn{8}{|c|}{ Non-monitored groups } \\
\hline G1 & G & 2 & 1 & 4 & 2 & 1 & 10 \\
\hline G3 & G & 2 & 2 & 1 & 1 & 2 & 8 \\
\hline G4 & G & 3 & 3 & 5 & 2 & 3 & 16 \\
\hline G5 & G & 1 & & 2 & & & 3 \\
\hline I1 & I & 1 & & & & & 1 \\
\hline $\mathrm{J} 2 / \mathrm{K} 1-\mathrm{AP}$ & $\mathrm{J}$ & 1 & 4 & 9 & 2 & 4 & 20 \\
\hline K2-AP & $\mathrm{K}$ & 2 & & 2 & & & 4 \\
\hline L1 & $\mathrm{L}$ & 1 & & 1 & 1 & & 3 \\
\hline L2 & $\mathrm{L}$ & 3 & 5 & 5 & 3 & 5 & 21 \\
\hline M1 & M & 1 & 3 & 3 & 1 & 3 & 11 \\
\hline N1 & $\mathrm{N}$ & 1 & & & & & 1 \\
\hline $\mathrm{N} 2$ & $\mathrm{~N}$ & 1 & & & & & 1 \\
\hline $\mathrm{O} 1$ & $\mathrm{O}$ & 1 & 2 & 5 & 1 & 2 & 11 \\
\hline Q1 & $Q$ & 2 & 1 & 4 & 2 & 1 & 10 \\
\hline Q2 & $Q$ & 2 & & 3 & 1 & & 6 \\
\hline R1 & $\mathrm{R}$ & 2 & 2 & 2 & 2 & 2 & 10 \\
\hline R2 & $\mathrm{R}$ & 1 & & 2 & 2 & & 5 \\
\hline R3 & $\mathrm{R}$ & 1 & 1 & 5 & 4 & 1 & 12 \\
\hline U1-AP & $\mathrm{U}$ & 3 & 2 & 5 & 2 & 2 & 14 \\
\hline U1-DG & $\mathrm{U}$ & 1 & & & & & 1 \\
\hline W1R & W & 1 & & 2 & 1 & & 4 \\
\hline WR3 & W & 1 & & 2 & & & 3 \\
\hline $\mathrm{X} 1$ & $x$ & 1 & & 3 & & & 4 \\
\hline$C^{\prime} 1$ & $C^{\prime}$ & 3 & 3 & 2 & 4 & 3 & 15 \\
\hline$C^{\prime} 2$ & $\mathrm{C}^{\prime}$ & 3 & 1 & 3 & 3 & 1 & 11 \\
\hline$C^{\prime} 3$ & $\mathrm{C}^{\prime}$ & 1 & 2 & 1 & 1 & 2 & 7 \\
\hline$C^{\prime} 5$ & $\mathrm{C}^{\prime}$ & 1 & & & & & 1 \\
\hline $\mathrm{D}^{\prime} 2$ & $\mathrm{D}^{\prime}$ & 1 & & & & & 1 \\
\hline$E^{\prime} 2$ & $\mathbf{E}^{\prime}$ & 1 & & 1 & & & 2 \\
\hline $\mathrm{G}^{\prime} 2$ & $\mathrm{G}^{\prime}$ & 1 & & & & & 1 \\
\hline $\mathrm{G}^{\prime} 3$ & $\mathrm{G}^{\prime}$ & 2 & & 2 & 3 & & 7 \\
\hline Total & & 48 & 32 & 74 & 38 & 32 & 224 \\
\hline \multicolumn{8}{|c|}{ Monitored groups } \\
\hline Research & & G2 & 1 & 8 & & 4 & 13 \\
\hline Mubare & $\mathrm{G}^{\prime} 1$ & 1 & 5 & & 6 & 4 & 16 \\
\hline Katendegere & $F^{\prime} 2$ & 1 & 1 & 1 & 1 & 4 & \\
\hline Ibare & $E^{\prime} 1$ & 2 & 4 & 7 & 2 & 8 & 23 \\
\hline Total & & 5 & 18 & 7 & 9 & 17 & 56 \\
\hline
\end{tabular}

in the Virungas during the 1970s and early 1980s. However, as the Virunga population started to increase, the proportion of immature gorillas increased, up to a published maximum of 48 per cent in 1986 (Vedder, 1986). Although direct inferences on population dynamics cannot be made from the proportion of immatures alone (Caughley, 1977), these comparisons with the Virungas indicate that the relatively low proportion of immature gorillas in the Bwindi population at present is consistent with a population that is not growing, or with a population where adult survival is considerably longer.

\section{Distribution of gorillas within Bwindi}

The locations of gorilla groups found in the course of the census are shown in Fig. 2 . There are clearly areas of the park which were not used by gorillas during the 7-week census, which might suggest room for expansion. Very limited information is available for Bwindi on the availability of different habitat types, the quality of these habitats in terms of gorilla food availability and gorilla habitat utilization patterns. It is difficult, therefore, to assess to what degree the population has the potential to increase.

As in previous surveys (Harcourt, 1981; Butynski, 1985), no gorillas were found within the northern part of the park. The northern part $(1200-1750 \mathrm{~m})$ is generally at a lower altitude than the south (1500-2800 m), and shows differences in habitat that may explain the lack of gorillas there. However, it cannot be concluded that gorillas could not utilize these lower habitats because the right food plants do not occur at lower altitudes. 


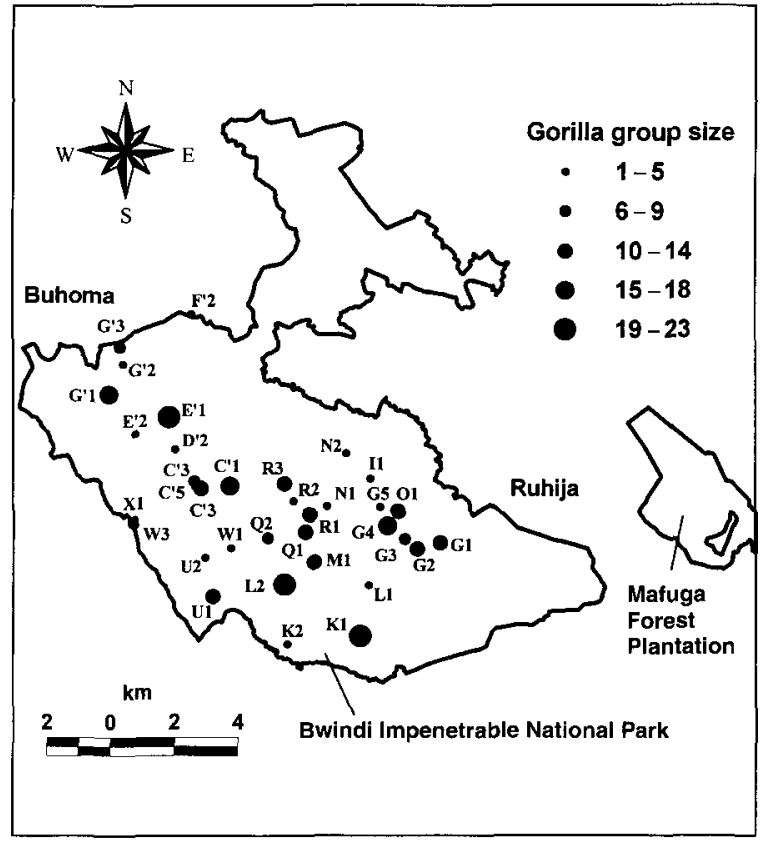

Fig. 2 Gorilla groups found during the census in Bwindi. Locations are taken from the mean co-ordinates of the three nest sites visited. Groups are represented with circles of differing radius dependent upon group size.

In Kahuzi-Biega National Park in eastern DRC, Grauer's gorilla Gorilla gorilla graueri are found both in a higher sector comparable in altitude to Bwindi, and in an extensive area of lowland forest (Hall et al., 1998).

Within the southern part of Bwindi, gorillas were mostly concentrated in the central region. No gorillas were found in the eastern end, which is the highest part of the park with a mix of bamboo and herbaceous vegetation. Recent research shows that gorillas in Bwindi will eat bamboo shoots when encountered (J.B. Nkurunungi, pers. comm.), and this area probably represents potential gorilla habitat. This would be expected because the home ranges of several groups in the Virungas consist almost exclusively of a similar mix of bamboo and herbaceous vegetation (McNeilage, 1995).

The vegetation in the western end of Bwindi (Plate 3) also differs from the rest of the southern part, being at a lower altitude, but gorillas were found in this area. We cannot be certain that other patterns of variation in vegetation could not explain why gorillas avoid other exterior parts of the park, but no changes in vegetation towards the exterior were obvious in the course of fieldwork except those at the eastern and western ends.

\section{Human disturbance}

Signs of human disturbance encountered during the Bwindi census are summarized in Table 2, and the

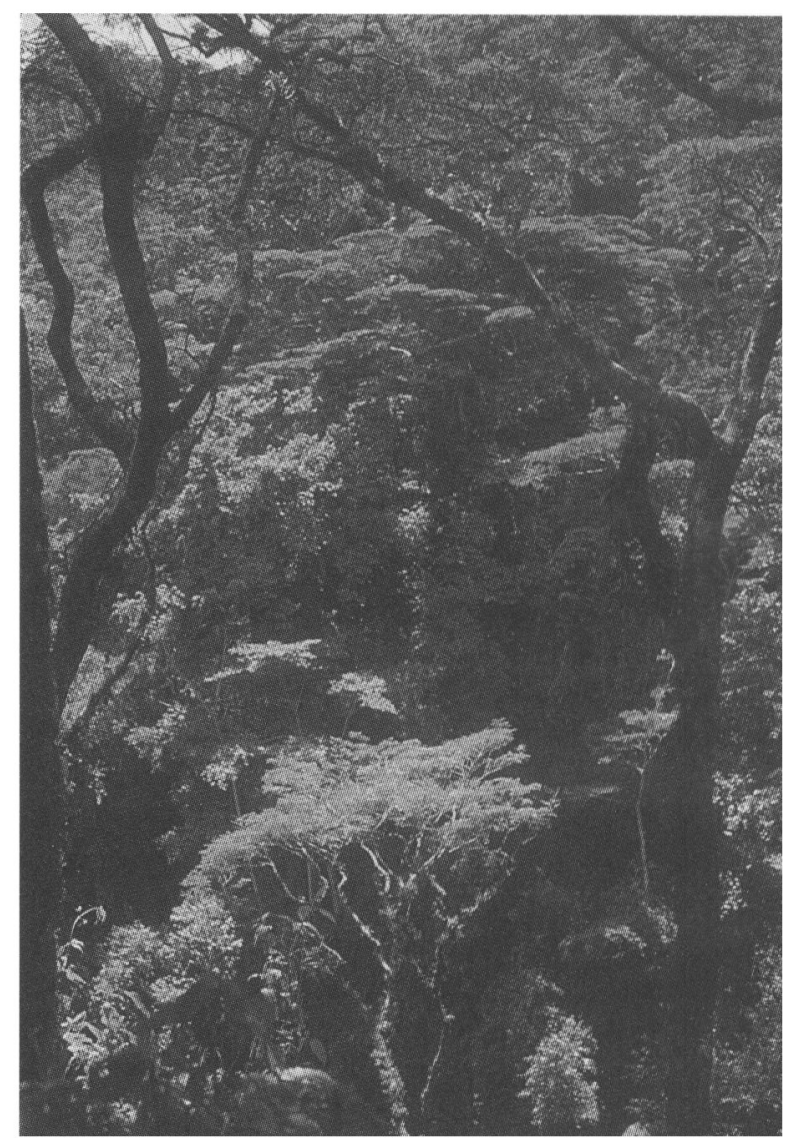

Plate 3 Forest at the lower altitudes in the west of Bwindi contain trees up to $40-50 \mathrm{~m}$ in height (Andrew Plumptre).

Table 2 Total number of occurrences of each form of human disturbance found in Bwindi during the 1997 gorilla census.

\begin{tabular}{ll}
\hline Illegal human sign & $\begin{array}{l}\text { Total number } \\
\text { of occurrences }\end{array}$ \\
\hline Beehives & 82 \\
Snares & 62 \\
Pitsawing sites - old & 53 \\
Human trails (poachers or others) & 34 \\
Wood cutting (firewood, poles, etc.) & 28 \\
Fireplaces (usually poachers'camps) & 21 \\
Gold mining pits - old & 6 \\
Pitfall traps - old & 6 \\
Honey gathering & 4 \\
Pitsawing sites - new & 3 \\
Poachers & 1 \\
\hline
\end{tabular}

distribution of the most common forms of disturbance is shown in Fig. 3. Disturbance was clearly not evenly distributed over the park, and different types of disturbance were concentrated in different areas. Such disturbance could have an impact on the gorillas' use of particular areas. The most frequently encountered signs were beehives, but the majority of these ( 68 of 82 ) were 


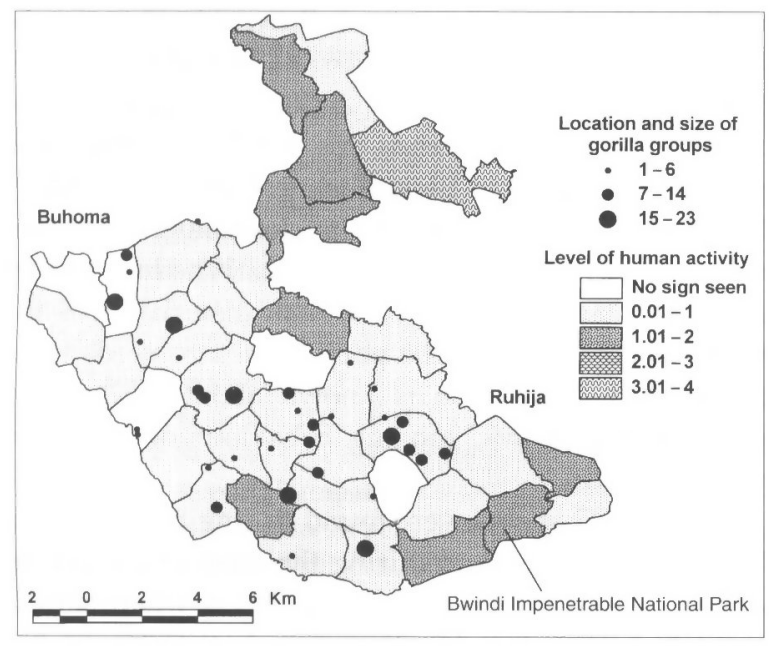

Fig. 3 The distribution of human disturbance across the park. The shading shows the relative encounter rates of all human signs in the park classified into four intervals. The distribution of gorilla groups is also shown.

found within the sectors which include multiple-use zones in which beehives can legally be maintained within the park. These zones extend up to a maximum of $2 \mathrm{~km}$ into the interior of the park. Pitsawing sites were common, although most of these were old, predating the gazetting of Bwindi as a national park. Only three new pitsawing sites were encountered, all in the northern part of the park. Snares, fireplaces, human trails and cutting for firewood or poles were all encountered more frequently.

The rate of encounter of gorilla nest sites per $\mathrm{km}$ in each sector was used to examine the relationship between the distribution of human disturbance and that of gorillas. Gorilla nests were concentrated in the centre of the park (Fig. 3), as were the actual groups found
(Fig. 2). Spearman's rank correlations are shown in Table 3. The northern part of the park, where no gorillas were found, was excluded from the analysis. Perhaps surprisingly, gorilla nests were positively correlated with fireplaces, and showed a non-significant positive correlation with snares. Gorilla nests were negatively correlated with beehives.

The correlations between gorilla nests and signs of poaching could be the result of the fact that both are apparently more concentrated in the centre of the forest. Similarly, beehives tend to be found in the exterior parts, which would explain the negative correlation with gorilla nests. In order to investigate this further, sectors were divided into those sharing a boundary with the edge of the park (exterior, $n=20$ ) and those completely surrounded by other sectors (interior, $n=14$ ). Gorilla nests were encountered significantly more often in interior sectors (interior -3.6 nest sites per $\mathrm{km}$, exterior -0.95 per $\mathrm{km}$, Mann-Whitney $U=62$, $P=0.005$ ). Comparisons for human disturbance are shown in Table 3 . Beehives were encountered significantly more often in exterior sectors. The situation with other signs of human disturbance is less clear; encounter rates were not significantly different in interior and exterior sectors, although there is a suggestion that poaching signs are generally more common in the interior. There are also some types of human disturbance which do not leave many signs and therefore could not be measured in this survey. Tourist and research activities are two such activities. Where humans are using the forest for tourism around Buhoma and research around Ruhija (Fig. 2) their presence may cause unhabituated gorillas to avoid these areas. However, there is little quantifiable sign that can be measured in the forest to indicate these types of use of the forest. Paths were counted in this survey which would

Table 3 The most common forms of human disturbance in the southern part of Bwindi and their relationship to the distribution of gorillas Spearman's correlation coefficients are given for the relationships between signs of human disturbance and gorilla nests in the sectors in the southern part of the park $(n=34)$. Comparisons are also given of the encounter rates (number encountered per $\mathrm{km}$ ) between exterior sectors (those with a boundary at the exterior of the park) and interior sectors. Comparisons were made using Mann-Whitney $U$-tests.

\begin{tabular}{|c|c|c|c|c|c|}
\hline Illegal human sign & $\begin{array}{l}\text { Number of } \\
\text { occurrences in } \\
\text { southern part }\end{array}$ & $\begin{array}{l}\text { Correlation with } \\
\text { gorilla nests } \\
\text { (number per } \mathrm{km} \text { ) }\end{array}$ & $\begin{array}{l}\text { Exterior sectors } \\
n=20 \\
\text { (number per } \mathrm{km} \text { ) }\end{array}$ & $\begin{array}{l}\text { Interior sectors } \\
n=14 \\
\text { (number per } \mathrm{km} \text { ) }\end{array}$ & $\begin{array}{l}\text { Test between } \\
\text { exterior and } \\
\text { interior }\end{array}$ \\
\hline Snares & 55 & 0.26 & 0.07 & 0.14 & NS \\
\hline Fireplaces & 21 & $0.43^{*}$ & 0.02 & 0.07 & NS \\
\hline Total poaching signs (i.e. snares + fireplaces) & 76 & 0.32 & 0.09 & 0.20 & NS \\
\hline Wood cutting (firewood, poles, etc.) & 28 & 0.26 & 0.05 & 0.05 & NS \\
\hline Beehives & 82 & $-0.40^{*}$ & 0.22 & 0.02 & $0.02^{*}$ \\
\hline Total non-poaching signs & 121 & 0.01 & 0.28 & 0.08 & NS \\
\hline Human trails (poachers or others) & 23 & 0.08 & 0.04 & 0.08 & NS \\
\hline Total human disturbance signs & 220 & 0.12 & 0.41 & 0.36 & NS \\
\hline
\end{tabular}

${ }^{*} P<0.05$, two-tailed.

NS - Not significant.

(C) $2001 \mathrm{FFI}$, Oryx, 35(1), 39-47 
have included tourist trails and research trails as well as poachers' trails.

In summary, snares and other signs of poaching do not seem to have a negative impact on the distribution of gorillas in Bwindi. Although gorilla distribution was negatively correlated with other forms of disturbance, this does not necessarily imply a causal relationship. We cannot, therefore, say why gorillas use the interior of the park more than the exterior, but some aspects of human disturbance may be important. It was quite noticeable that the footpaths within multiple-use zones leading to beehives were open and well worn, indicating more frequent human presence than poachers' trails elsewhere. This in itself might have an impact on the gorillas; signs of gorillas and signs of human usage have been shown to be negatively correlated in the Virungas (McNeilage, 1995). It is vital that the effects of multipleuse zones on the gorillas and other wildlife be investigated and monitored over time. Past pitsawing in Bwindi would have changed the vegetation, probably improving the habitat for gorillas, and this will also confuse this analysis of the impacts of human disturbance on gorilla distribution.

It is also possible that levels of human disturbance are much lower than they used to be because of increased support to the park, but the gorillas are still using the centre of the park because this is where they have ranged historically. As a result, the history of disturbance in particular areas might influence gorilla distribution. Both Harcourt (1981) and Butynski (1985) found a similar pattern with gorillas favouring the interior of the forest. Harcourt (1981) found that human use was most common near the periphery as would be expected and that gorilla sign was more common where human sign was less common. Protection of Bwindi has been improved considerably since 1986 (Butynski \& Kalina, 1993). Butynski (1985) found 89 snares while walking around $200 \mathrm{~km}$ of survey trail with only one or two guides, whereas 62 snares were found in over $500 \mathrm{~km}$ walked during the 1997 census, in which many more people participated. This low level of poaching sign may explain why the correlations between gorillas and poaching sign are not significant; the density is just too low. Although heavy human use may have been reduced in recent years, it may still have a legacy in terms of the areas favoured by gorillas.

\section{Conclusions}

The size of the gorilla population in Bwindi appears to be fairly stable and has not changed much since 1993 . We do not know why the population is not increasing, or the number of gorillas the park could support. Over an 8-year period (1981-1989) the Virunga population increased by about 25 per cent. Butynski surveyed the Bwindi population between 1986 and 1993 during which time it remained fairly stable at 300 (T. Butynski, pers. comm.). Our census extends this stability to 1997 . Four gorillas were killed in Bwindi in 1994, but it is unlikely that more were killed given the close monitoring that has gone on since the late 1980s. Whether habitat availability, social factors or human disturbance is the primary cause limiting the population size needs to be investigated. Very little is known about gorilla diet, habitat requirements, ranging behaviour or demography in Bwindi.

Although 62 snares were found during this census of Bwindi, 414 were found during the most recent census of the Virungas in 1989 (McNeilage, 1995), where similar methods were used. Hunting sign is therefore much lower than was the case in the Virungas. Although protection in Bwindi has improved in recent years, and poaching may be less of a problem than in other areas, there is no room for complacency. Given the small area of the park, the small size of the gorilla population, and the prevalence of illegal human disturbance which remains, improved protection should continue to be an important priority.

\section{Acknowledgements}

The 1997 Bwindi gorilla population census was funded jointly by the WCS and the IGCP. In addition, the UWA and the ITFC provided extensive manpower, equipment and logistical assistance. We are particularly grateful to Keith Musana (UWA), Liz MacFie (IGCP), Richard Malenky and Nancy Thompson-Handler (ITFC) for their help. L'Institut Congolais pour la Conservation de la Nature, L'Office Rwandais de Tourism et Parcs Nationaux and Dian Fossey Gorilla Fund International also provided personnel for the census. We are extremely grateful to team leaders Banard Akunda, Venance Betowabo, Phenny Gongo, Maryke Gray, David Greer, Robin Heber-Percy, Chad Hudson, Omari Ilambu, Gladys Kalema, Roger Mathews, Godfrey Mayoba, Deo Mbula, Gapira Mutazimiza, Barakabuye Nsengiyumva, Levi Rwamuhanda and Liz Williamson; and to the many guides, guards, trackers, drivers, cooks and porters who are too numerous to mention but without whose efforts the census would not have been possible. Patagonia kindly donated raingear.

\section{References}

Butynski, T.M. (1984) Ecological Survey of the Impenetrable (Bwindi) Forest, Uganda, and Recommendations for its Conservation and Management. New York Zoological Society Report, New York. 
Butynski, T.M. (1985) Primates and their conservation in the Impenetrable (Bwindi) forest, Uganda. Primate Conservation, 11, 31-41.

Butynski, T.M. \& Kalina, J. (1993) Three new mountain national parks for Uganda. Oryx, 27, 214-224.

Butynski, T.M. \& Kalina, J. (1998) Gorilla tourism: a critical look. In Conservation of Biological Resources (eds E.J. MilnerGulland and R. Mace), pp. 280-300. Blackwell Science, Oxford.

Caughley, G. (1977) Analysis of Vertebrate Populations. John Wiley and Sons, London.

Davenport, T., Howard, P.C. \& Mathews, R. (1996) Bwindi Impenetrable National Park Biodiversity Report. Uganda Forest Department Report, Kampala.

Gubelman, E., Schoorl, J. \& Achóka, I. (1995) Bwindi Impenetrable National Park Management Plan 1995-99. Uganda Wildlife Authority, Kampala.

Hall, J.S., White, L.J.T., Inogwabini, B.I. et al. (1998) A survey of Grauer's gorillas (Gorilla gorilla graueri) and chimpanzees (Pan troglodytes schweinfurthi) in the Kahuzi Biega National Park lowland sector and adjacent forest in eastern Congo. International Journal of Primatology, 19, 207-235.

Hamilton, A.C. (1976) The significance of patterns of distribution shown by forest plants and animals in tropical Africa for the reconstruction of upper-Pleistocene paleoenvironments: a review. Paleoecology Africana, 9, 63-97.

Harcourt, A.H. (1981) Can Uganda's gorillas survive? A survey of the Bwindi forest reserve. Biological Conservation, 19, 269282.

Harcourt, A.H., Kineman, J., Campbell, G., et al. (1983) Conservation of the Virunga gorilla population. African Journal of Ecology, 21, 139-142.

Howard, P.C. (1991) Nature Conservation in Uganda's Tropical Forest Reserves. IUCN, Gland.

Keith, S. (1980) The avifauna of the Impenetrable Forest, Kigezi, Uganda, with special reference to altitudinal distribution. Proceedings of the IV Pan African Ornithological Congress, pp. 159-167. Lilongwe, Malawi.

McNeilage, A. (1995) Mountain gorillas in the Virunga Volcanoes: ecology and carrying capacity. PhD Thesis, University of Bristol, Bristol.

Sarmiento, E.E., Butynski, T.M. \& Kalina, J. (1996) Gorillas of Bwindi-Impenetrable Forest and the Virunga Volcanoes: Taxonomic implications of morphological and ecological differences. American Journal of Primatology, 40, 1-21.

Schaller, G.B. (1963) The Mountain Gorilla: Ecology and Behaviour. University of Chicago Press, Chicago.

Sholley, C.R. (1991) Conserving gorillas in the midst of guerrillas. American Association of Zoological Parks and Aquariums, Annual Conference Proceedings, pp. 30-37.

Sikubwabo, C. \& Mushenzi, N. (1997) Mountain gorillas of Mikeno, Zaire: an explosive situation. Gorilla Conservation News, 11, 13-14.

Stewart, K. (1998) More news from the Democratic Republic of Congo (formerly Zaire), 1997. Gorilla Conservation News, 12,17 .
Vedder, A. (1986) Virunga Mountain Gorilla Census. Co-ordinator's Report, Wildlife Conservation Society, New York.

Weber, A.W. \& Vedder, A. (1983) Population dynamics of the Virunga gorillas 1959-78. Biological Conservation, 26, 341-366.

\section{Biographical sketches}

Alastair McNeilage is currently the Director for the Institute for Tropical Forest Conservation in the Bwindi Impenetrable National Park; he has been studying the ecology of gorillas since 1989. His PhD research, from Bristol University, was based at the Karisoke Research Centre in Rwanda and looked at the feeding ecology and ranging of gorilla groups in different areas of the Virunga Volcanoes. Following this he worked with Dr Diane Doran for 2 years to establish a field station at Mondika in the Central African Republic to study lowland gorilla ecology.

Andrew J. Plumptre is currently the Assistant Director for the Africa Programme of the Wildlife Conservation Society, based in New York. In 1991, he completed his PhD at Bristol University on the impact of large herbivores, including gorillas, on the vegetation of the Virunga Volcanoes. Following this he helped to establish the Budongo Forest Project in western Uganda and undertook research on the impacts of selective logging on wildlife for 6 years. In 1997, he started his current post.

Andy Brock-Doyle was deputy project manager of the International Gorilla Conservation Programme in Uganda between April and November 1997. During 1998/1999 he was project co-ordinator for the Zambezi Basin Initiative for Biodiversity and Conservation in Zimbabwe. He is currently completing an MSc in Protected Landscape Management at the University of Wales, Aberystwyth by writing a thesis on the effectiveness of protected area management.

Amy Vedder currently heads the 'Living Landscapes' programme of the Wildlife Conservation Society. Her PhD fieldwork, from the University of Wisconsin, was based at Karisoke Research Centre and looked at gorilla feeding and ranging ecology. She and her husband, Bill Weber, established the Mountain Gorilla Project and started gorilla tourism in Rwanda following her fieldwork. She then helped to highlight the conservation importance of the Nyungwe Forest Reserve and started a research and tourism programme there, the Projet Conservation de la Foret de Nyungwe. She was then Director of Africa Programmes at the Wildlife Conservation Society until she took up her current position. 